\title{
EFFECT OF HELICOBACTER PYLORI INFECTION ON THE OCCURRENCE OF ESOPHAGEAL REFLUX DISEASE
}

\author{
Vesna Brzački1,2, Danijela Benedeto-Stojanov ${ }^{1,2}$
}

\begin{abstract}
The role of Helicobacter pylori (H. pylori) in the emergence of gastroesophageal reflux disease (GERD) is quite unclear. It is suggested that $H$. pylori has the protective role in esophageal disease development. The aims of the present study were to analyze the frequency of $H$. pylori infection in patients with different forms of GERD and comparison of incidence between the different groups, relation between the degree of esophagitis and $H$. pylori infection in patients with ERD, histological changes in the esophagus and cardia after eradication therapy in patients of both groups who were positive for $\mathrm{H}$. pylori, and to compare ERD and NERD after conducting eradication therapy for $\mathrm{H}$. pylori infection. Prospective study conducted in the Clinic of Gastroenterology, Clinical Center in Niš, included 90 patients with symptoms of GERD. Patients were divided into two groups according to whether they have endoscopic signs of gastroesophageal reflux (ERD group), or absence of signs of reflux (NERD group). Two biopsies of the antrum and corpus, and 4 esophageal biopsies within $2 \mathrm{~cm}$ of the $Z$ line were performed in all patients during the proximal endoscopy. In the gastric mucosa biopsy, we investigated the presence of $H$. pylori infection, as well as histomorphological changes by hematoxylin eosin and modified Giemsa method. The degree of esophagitis was determined by the Los Angeles classification. In $H$. pylori positive patients, eradication therapy was administered for a period of ten days. After eradication of H.pylori and treatment of reflux disease for 8 weeks with proton pump inhibitors, esophagus biopsy was repeated. In the antrum, H. pylori was positive in 22 $(44.89 \%)$ subjects of the ERD group compared to $30(66.66 \%)$ of the NERD group. In the corpus, $H$. Pylori was positive in $18(40.00 \%)$ subjects of the ERD group compared to 24 $(53.33 \%)$ subjects of the NERD group, and no statistical significance was found. In the ERD group, there was no difference in the presence or absence of $H$. pylori infection and severity of esophagitis. After eradication, in both groups of patients, there was a statistically significant improvement in histological findings $\left(\chi^{2}=22.26 ; p=0.00001\right)$. After the treatment in the ERD group, there was statistically significant decrease in endoscopic findings of esophagitis. After the treatment in the group of subjects with NERD, three patients had endoscopic findings of esophagitis. In patients with GERD, a long-term anti secretory therapy should be implemented and $H$. pylori needs to be tested and eradicated. $H$. pylori positive status is rarely seen together with GERD, and if it is, it is of lower degree.
\end{abstract}

Acta Medica Medianae 2018;57(4):60-66.

Key words: GERB ERB, NERB, H. pylori

${ }^{1}$ University of Niš, Medical Faculty, Niš, Serbia

${ }^{2}$ Clinic of gastroenterology and hepatology, Clinical Center Niš, Serbia

Contact: Vesna Brzački

Bul.dr Zoran Djindjić 37/52, 18000 Niš, Serbia

E-mail: brzackiv@gmail.com

\section{Introduction}

Helicobacter pylori (H. pylori) is one of the leading pathogenic factors in the development of gastroduodenal ulceration, dyspepsia and gastric adenocarcinoma. Its role in the emergence of gastroeso- phageal reflux disease (GERD) is quite unclear and has been the subject of numerous studies. In developed countries, decreasing prevalence of $H$. pylori infection reduced the peptic ulcer disease and adenocarcinoma of the distal stomach. At the same time, there has been an increase in GERD, Barrett's esophagus, adenocarcinoma of distal esophagus and proximal stomach, suggesting a protective role of $H$. pylori in the development of esophageal disease.

The term GERD is used to describe symptoms and esophageal mucosal changes, as a result of the reflux of gastric contents into the esophagus. Peptic esophagitis, reflux esophagitis and erosive esophagitis, erosive reflux disease (ERD) are synonyms for GERD with histopathological changes of esophageal mucosa that usually correlate with the symptoms of acid content reflux (1). Damages of the esophageal mucosa occur due to reflux of gastric contents into 
the esophagus and the harmful effects of hydrochloric acid and pepsin. The severity of epithelial changes is assessed by the presence of symptoms or endoscopic signs. The majority of patients with GERD present with clinical manifestations of mild to mode-rate degree of illness.

In recent years, in gastroenterological literature, there has been the term of non-erosive reflux disease-NERD (2) for patients with symptomatic GERD who have no macroscopic mucosal changes during the proximal endoscopy. It is estimated that $50-70 \%$ of patients with GERD have NERD $(2,3)$.

Adequate assessment of reflux disease solely on the basis of endoscopy is difficult due to the existence of normal endoscopic findings of the esophagus in NERD. Some authors described the histological changes in GERD, so it seems reasonable that the diagnosis of NERD can be set by taking a biopsy during endoscopy. In the last three decades, there have been histological criteria for reflux disease: basal cell proliferation, regenerative elongation and increase in the number of epithelial papillae, increase in the number and ectasia of capillaries in the epithelial papillae, glycogenic acanthosis in basal epithelium, the presence of the so-called "Balloon cells" (acid-induced degenerative changes in basal epithelium), dilatation of the intracellular space in the parabasal areas of basal epithelium, neutrophils, eosinophils and $\mathrm{T}$ lymphocytes infiltration.

In recent years, in patients with GERD, Lugol solution has been applied during endoscopy (chromoendoscopy). Lugol solution is a mixture of iodine and potassium iodide which shows an affinity for glycogen in non keratinized squamous epithelium. Normal esophageal epithelium is rich in glycogen and it gradually turns black, dark-brown or green-brown shortly after application. Mucosal changes that have a small amount of glycogen, if any, will not be stained after application of Lugol solution (4).

\section{Aims}

The aims of the present study were to:

- Analyze the frequency of $H$. pylori infection in patients with different form of GERD and comparison of incidence between the different groups,

- Analyze the relation between the degree of esophagitis and Helicobacter pylori infection in patients with ERD,

- Analyze the histological changes of the esophagus and cardia after the eradication therapy in patients of both groups who were positive for Helicobacter pylori,

- Compare ERD and NERD after conducting eradication therapy for $H$. pylori infection.

\section{Material and methods}

A prospective study conducted in the Clinic of Gastroenterology, Clinical Center Niš, included 90 patients with symptoms of gastroesophageal reflux disease. Patients were divided into two groups according to whether they have endoscopic signs of gastroesophageal reflux (ERD group), or absence of signs of reflux (NERD group). Of all patients, 52 (57.77\%) were men and 38 (42.23\%) were women. There were 24 men in the ERD group, and 28 in the NERD group. There were 17 women in the ERD group, and 21 in the NERD group. The average age of patients in the ERD group was 62.5 years, and in the NERD group 58.1 years. The majority of patients were in the sixth and seventh decade of life.

In all patients during the proximal endoscopy (esophagogastroduodenoscopy), we macroscopically evaluated esophageal, stomach and duodenum mucosa to the border of the descending and horizontal part of the duodenum. Macroscopic mucosal changes of the distal esophagus were measured on the basis of the distance from the $Z$ line, and mucosal damage was classified according to the Los Angeles classification of reflux esophagitis.

In all patients during the proximal endoscopy two biopsies of the antrum and corpus were taken and four esophageal biopsies within $2 \mathrm{~cm}$ of the $Z$ line. In the gastric mucosa biopsy, we investigated the presence of $H$. pylori infection, as well as histomorphological changes by hematoxylin eosin and modified Giemsa method. In $H$. pylori positive patients, eradication therapy was administered for a period of ten days. After eradication of H.pylori and treatment of reflux disease for 8 weeks with proton pump inhibitors, esophagus biopsy was repeated.

\section{Results}

1. The incidence of $H$. pylori infection in patients the ERD and NERD group of the ERD and NERD group.

In the antrum, $H$. pylori was positive in 22 (44.89\%) patients of the ERD group, in relation to the $30(66.66 \%)$ subjects of the NERD group. $H$. pylori was negative in 23 (51.11\%) patients of the ERD group, in relation to $15(33.33 \%)$ patients of the NERD group. In the corpus, H. pylori was positive in $18(40.00 \%)$ patients of the ERD group in relation to $24(53.33 \%)$ patients of the NERD group. $H$. pylori was negative in $27(60.00 \%)$ subjects of the ERD group compared to 21 (46.66\%) negative subjects of the NERD group. There was no statistically significant difference in the incidence of $H$. pylori infection between the two groups (Graph 1).

2. The degree of esophagitis and $H$. pylori infection in patients of the ERD group.

In respect of $H$. pylori infection, there was no difference in the presence or absence of H.pylori infection and the level of esophagitis (Table 1 ). 


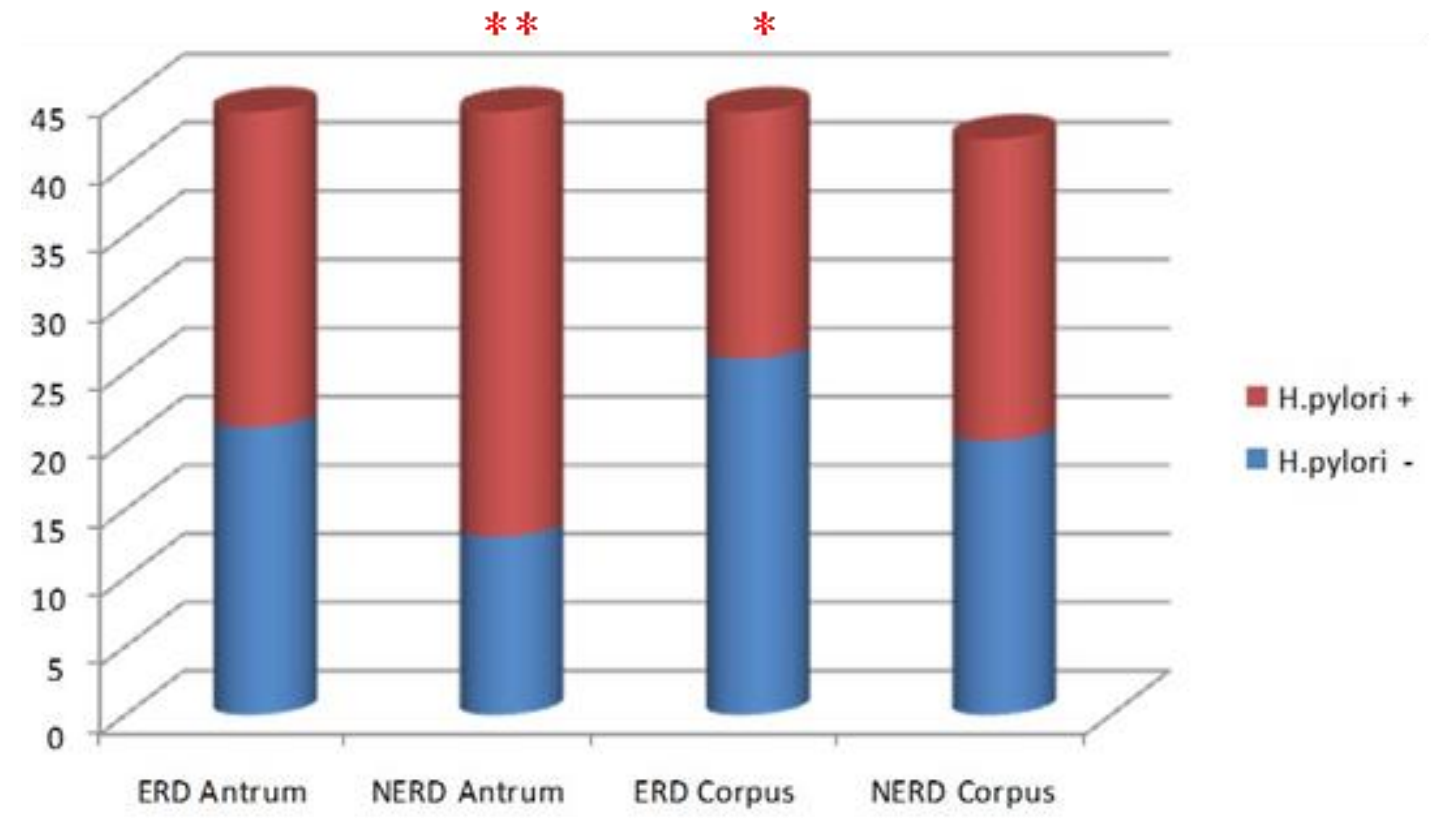

$*_{-} \mathrm{p}=0,049$ H.p. (+) vs. H.p. (-) $\quad * *_{-} \mathrm{p}=0,001$ vs. H.p. (+) vs. H.p. (-)

Graph 1. H. pylori infection of the corpus and antrum in the ERD and NERD groups

Table 1. The degree of esophagitis and $H$. pylori infection in patients of the ERD group.

\begin{tabular}{||lcccccc||}
\hline \multicolumn{1}{|c}{ Group } & N & \multicolumn{4}{c||}{ The degree of esophagitis } \\
\hline \multirow{2}{*}{ ERD $(\mathbf{n}=\mathbf{4 5})$} & & A & B & C & D \\
\cline { 3 - 7 } & & & 12 & 29 & 4 & 0 \\
& & & $(26.66 \%)$ & $(64.44 \%)$ & $(8.88 \%)$ & \\
\hline \multirow{2}{*}{ Corpus } & H. pylori (+) & 18 & 2 & 10 & 5 & 1 \\
& H. pylori (-) & 27 & 7 & 11 & 4 & 5 \\
\hline \multirow{2}{*}{ Antrum } & H. pylori (+) & 22 & 3 & 12 & 5 & 2 \\
& H. pylori (-) & 23 & 6 & 9 & 4 & 4 \\
\hline
\end{tabular}

3. Histological changes of the esophagus after eradication therapy in patients of both groups who were $H$. pylori positive

After eradication therapy, in the group of patients with ERD and in the group of patients with NERD, there was a statistically significant decrease of histological findings of multiplied papilla, $p=$ 0.00001 . After eradication therapy in the ERD group, there was a statistically significant decrease of elongated papilla findings, $p=0.001$. There was also a decrease in the NERD group, but with no statistical significance. There was a statistically significant decrease of basal cells hyperplasia in both the ERD group ( $p=0.00001)$ and the NERD group ( $p=$ 0.001 ). There was a statistically significant decrease in histological findings of vascular dilatation in both the ERD group ( $p=0.00001)$ and the NERD group $(p=0.002)$. After eradication therapy there was a statistically significant decrease in histological findings of balloon cell in both the ERD group ( $p=$ $0.00002)$, and the NERD group ( $p=0.002)$. There was a statistically significant decrease in histological findings of cells maturation absence in the ERD group $(p=0.03)$. There was a statistically significant decrease in mitotic activity increase in both the ERD group ( $p=0.00003)$, and the NERD group ( $p=$ 0.03 ). There was a statistically significant decrease of polymorphonuclear leukocytes infiltration in both the ERD group $(p=0.0001)$, and the NERD group $(p=0.00001)$ (Table 2).

4. The degree of esophagitis after treatment

After treatment, in the group of subjects with $E R D$, there was a statistically significant decrease in 
endoscopic findings of esophagitis $\left(\chi^{2}=22.26 ; p=\right.$ 0.00001 ) (Table 3 ). After treatment, in the group of subjects with a NERD, three patients had esophagitis.

Table 2. Comparison of histological changes of the esophagus between the ERD and NERD groups before and after therapy.

\begin{tabular}{|c|c|c|c|c|}
\hline \multirow{4}{*}{$\begin{array}{l}\text { multiplied papilla - before therapy } \\
\text { multiplied papilla - after therapy }\end{array}$} & \multicolumn{2}{|c|}{ ERD $(n=23)$} & \multicolumn{2}{|c|}{ NERD $(n=31)$} \\
\hline & + & - & + & 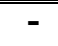 \\
\hline & 23 & 0 & 22 & 9 \\
\hline & 9 & 14 & 9 & 22 \\
\hline$\chi^{2} / \mathbf{p}$ & \multicolumn{2}{|c|}{$20.13 / 0.0001$} & \multicolumn{2}{|c|}{$10.9 / 0.0009$} \\
\hline elongated papilla - before therapy & 22 & 1 & 17 & 14 \\
\hline elongated papilla - after therapy & 13 & 10 & 8 & 13 \\
\hline$\chi^{2} / \mathbf{p}$ & \multicolumn{2}{|c|}{$9.68 / 0.001$} & \multicolumn{2}{|c|}{-} \\
\hline basal cells hyperplasia - before therapy & 22 & 1 & 14 & 17 \\
\hline basal cells hyperplasia - after therapy & 6 & 17 & 3 & 28 \\
\hline$\chi^{2} / \mathbf{p}$ & \multicolumn{2}{|c|}{$23.37 / 0.00001$} & \multicolumn{2}{|c|}{$9.8 / 0.001$} \\
\hline vascular dilatation - before therapy & 14 & 7 & 8 & 23 \\
\hline vascular dilatation - after therapy & 0 & 23 & 0 & 31 \\
\hline$\chi^{2} / p$ & \multicolumn{2}{|c|}{$22.5 / 0.00001$} & \multicolumn{2}{|c|}{$9.2 / 0.002$} \\
\hline balloon cell - before therapy & 13 & 10 & 8 & 23 \\
\hline balloon cell - after therapy & 0 & 23 & 0 & 31 \\
\hline$\chi^{2} / \mathbf{p}$ & \multicolumn{2}{|c|}{$18.12 / 0.00002$} & \multicolumn{2}{|c|}{$9.19 / 0.002$} \\
\hline cells maturation absence - before therapy & 4 & 19 & 0 & 31 \\
\hline cells maturation absence - after therapy & 0 & 23 & 0 & 31 \\
\hline$\chi^{2} / \mathbf{p}$ & \multicolumn{2}{|c|}{$4.38 / 0.03$} & \multicolumn{2}{|c|}{-} \\
\hline decrease in mitotic activity- before therapy & 18 & 5 & 4 & 27 \\
\hline decrease in mitotic activity- after therapy & 4 & 19 & 0 & 31 \\
\hline$\chi^{2} / \mathbf{p}$ & \multicolumn{2}{|c|}{$17.08 / 0.00003$} & \multicolumn{2}{|c|}{$4.28 / 0.03$} \\
\hline $\begin{array}{l}\text { polymorphonuclear leukocytes infiltration -before } \\
\text { therapy }\end{array}$ & 23 & 0 & 27 & 4 \\
\hline $\begin{array}{l}\text { polymorphonuclear leukocytes infiltration - after } \\
\text { therapy }\end{array}$ & 12 & 11 & 5 & 26 \\
\hline$\chi^{2} / \mathbf{p}$ & 14.4 & 001 & 31. & 001 \\
\hline
\end{tabular}

Table 3. The degree of esophagitis after treatment in patients ERD and NERD groups

\begin{tabular}{|c|c|c|c|c|}
\hline & \multicolumn{2}{|c|}{ ERD $(n=23)$} & \multicolumn{2}{|c|}{ NERD $(n=31)$} \\
\hline & Esophagitis & Valid findings & Esophagitis & Valid findings \\
\hline Before therapy & $\begin{array}{c}23 \\
(100 \%)\end{array}$ & 0 & 0 & $\begin{array}{c}31 \\
(100 \%)\end{array}$ \\
\hline After therapy & $\begin{array}{c}8 \\
(34.78 \%)\end{array}$ & $\begin{array}{c}15 \\
(65.22 \%)\end{array}$ & $\begin{array}{c}3 \\
(9.67 \%)\end{array}$ & $\begin{array}{c}28 \\
(90.33 \%)\end{array}$ \\
\hline$\chi^{2} / \mathbf{p}$ & 22,26 & 00001 & & \\
\hline
\end{tabular}




\section{Discussion}

H. pylori causes chronic gastritis, which can progress in peptic ulcer, gastric atrophy and gastric cancer. The role of $H$. pylori infection in reflux esophagitis and the relationship between reflux esophagitis and atrophic gastritis has not been elucidated yet. GERD with or without reflux esophagitis is the leading cause of discomfort in the proximal part of the digestive tract. The main mechanism of reflux esophagitis includes the reduction in basal pressure of the lower esophageal sphincter (LES), and increase in the frequency of spontaneous transient relaxation of the LES. Gastric acid is also necessary for the development of symptoms and mucosal injury. The assumption that impaction $H$. pylori in the LES or a local acidic secretion may affect the appearance and disappearance of reflux esophagitis is understandable. Patients with duodenal ulcer or ulcer similar symptoms have increased acid secretion and they experienced symptoms similar to reflux esophagitis. On the other hand, reducing the production of gastric acid caused by $H$. pylori infection and the consequent atrophic gastritis may be protective factors in the occurrence of reflux disease (5).

In the group of patients with ERD, there is no significant difference in positive and negative findings of $H$. pylori infection comparing the antrum and corpus. Approximately the same number of patients has the infection both in the antrum and in the corpus. In the group of patients with a NERD there is no significant difference in positive and negative findings of $H$. pylori infection in the antrum and corpus. Approximately the same number of patients has the infection both in the antrum and in the corpus.

In relation to the antrum, there is a statistically significant difference in the occurrence of $H$. pylori infection. Twice as many patients were $H$. $p y-$ lori positive. In the antrum, $H$. pylori was positive in 22 patients with ERD compared to 30 positive patients in the NERD group. H. pylori was negative in the 23 patients with ERD compared to only 15 negative patients of the NERD group. In the corpus, $H$. pylori infection was positive in 18 patients of the ERD group, compared to 24 positive patients of the NERD group. $H$. pylori was negative in 27 patients with ERD, compared to 21 patients of the NERD group. There was no statistically significant difference in the incidence of $H$. pylori infection between the two groups. Our results show a higher number of $H$. pylori infection in the antrum and corpus in patients of the NERD group than in of the ERD group. Many authors suggested that $H$. pylori infection is rarely present in patients with reflux esophagitis, and that the atrophic gastritis has lower level as compared to patients without esophagitis. $H$. pylori infection is the main cause of atrophic gastritis and decreased acid secretion. Koike at al. have shown that the infection with $H$. pylori is significantly lower in patients with reflux esophagitis than in patients without it. There is also a positive correlation between the presence of $H$. pylori and severity of esophagitis. In patients with reflux esophagitis, there is increased acid secretion, indicating a possible connection between $H$. pylori and its protective effect on the occurrence of GERD (6).

Many authors suggest that $H$. pylori infection is negatively correlated with the occurrence of reflux esophagitis, at least in some populations. In other words $H$. pylori infection may protect some groups from developing reflux esophagitis. Many studies have shown that $H$. pylori infection is not associated with the severity of reflux esophagitis (7). After the eradication therapy in the NERD group there were three new cases of reflux esophagitis. Many mechanisms may be involved in the development of reflux esophagitis after eradication of $H$. pylori infection. Eradication of $H$. pylori infection leads to inflammation healing in the corpus of the stomach and normalized function of fundic glands (8). When we eradicate $H$. pylori, the preventive effect of the infection may disappear, allowing peptic gastroesophageal reflux.

Meta analysis summarizes the results of 20 studies and found that $H$. pylori negative status is associated with a significantly increased risk of GERD (9). Some studies suggest that $H$. pylori positive status is rarely seen together with GERD, and if it is present, GERD symptoms are milder in contrast to H. pylori negative patients (10).

\section{Conclusion}

1. In the NERD subjects, $H$. pylori infection is present more often than in the ERD group, which would support the protective role of $H$. pylori infection in the occurrence of reflux disease.

2. Eradication of $H$. pylori may be associated with transient reflux esophagitis.

3. Eradication of $H$. pylori infection can block the spread of atrophic gastritis and influence the regression of atrophy.

4. In patients with GERD, long-term antisecretory therapy should be implemented, $H$. pylori needs to be tested and eradicated, because longterm gastric acid suppression can accelerate the progression of Helicobacter pylori induced corpus atrophic gastritis. 


\section{References}

1. Jovanović I. Gastroezofagealna refluksna bolest jednjaka. Erozivni ezofagitis i simptomatska refluksna bolest (ERB i NERB). In: Nagorni A, editor. Dijagnostika i terapija bolesti digestivnog trakta povezanih sa pojačanom sekrecijom hlorovodonične kiseline. Niš: Prosveta; 2005. p. 23-30.

2. Nagorni A. Astma i gastroezofagealna refluksna bolest. In: Stanković I, editor. Bronhijalna astma. Niš: Medicinski fakultet Niš; 2005. p. 149-52.

3. Koop $H$, Schepp W, Mueller-Lissner S, Madisch A, Micklefield G, Messmann $\mathrm{H}$, et al. Consensus conference of the DGSV on gastro-esophageal reflux. Z Gastroenterol 2005; 43:163-93. [CrossRef] [PubMed]

4. Shim CS. Staining in gastrointestinal endoscopy: clinical application and limitations. Endoscopy 1999; 31:487-96. [CrossRef] [PubMed]

5. Ohara S, Sekine H, Iijima K, Moriyama S, Nakayama Y, Kinpara Tet, et al. Gastric mucosal atrophy and prevalence of Helicobacter pylori in reflux esophagitis of the elderly. Jpn J Gastroenterol 1996; 93:235-9. [PubMed]
6. Delaney B, McColl K. Review article: Helicobacter pylori and gastro-oesophageal reflux disease. Aliment Pharmacol Ther 2005; 22 (suppl 1):32-40. [CrossRef] [PubMed]

7. Ribeiro PF, Kubrusly LF, Nassif PA, Ribeiro IC Bertoldi AS, Batistão VC. Relationship between esophagitis grades and Helicobacter pylori. Arg Bras Cir Dig 2016; 29(3):135-7. [CrossRef] [PubMed]

8. Wang $X T$, Zhang $M$, Chen CY, Lyu B. Helicobacter pylori eradication and gastroesophageal reflux disease: a Meta-analysis. Zhonghua Nei Ke Za Zhi 2016; 55(9):710-6. [PubMed]

9. European Helicobacter pylori study group. Current European concepts in the management of Helicobacter pylori infection. The Maastricht Consensus Report. Gut 1997; 41:8-13. [CrossRef] [PubMed]

10. Wu DC,Kuo CH,Tsay FW,Hsu WH,Chen A,Hsu PI. A Pilot Randomized Controlled Study of Dexlansoprazole MR-Based Triple Therapy for Helicobacter Pylori Infection. Baltimor 2016; 95(11):e2698. [PubMed] 


\title{
UTICAJ HELICOBACTER PYLORI INFEKCIJE NA POJAVU REFLUKSNE EZOFAGEALNE BOLESTI
}

\author{
Vesna Brzački, ${ }^{1,2}$ Danijela Benedeto-Stojanov ${ }^{1,2}$
}

\author{
${ }^{1}$ Univerzitet u Nišu, Medicinski fakultet, Niš, Srbija \\ ${ }^{2}$ Klinika za gastroenterologiju i hepatologiju, Klinički centar Niš, Niš, Srbija
}

Kontakt: Vesna Brzački

Bul. dr Zoran Đinđić 37/52, 18000 Niš, Srbija

E-mail: brzackiv@gmail.com

Uloga Helicobacter pylori (H. pylori) u pojavi gastroezofagealne refluksne bolesti (GERB) je prilično nejasna. Smatra se da $H$. pylori infekcija preventivno deluje na pojavu GERB-a. Cilj ove studije bila je analiza učestalosti $H$. Pylori infekcije kod bolesnika sa različitim oblikom GERB-a i poređenje učestalosti između različitih grupa, povezanost stepena ezofagitisa i $H$. pylori infekcije kod bolesnika sa erozivnom refluksnom bolešću (ERB), histoloških promena jednjaka nakon eradikacije bolesnika obe grupe koji su bili pozitivni na $H$. pylori i poređenje ERB i NERB nakon eradikacione terapije za $H$. pylori infekcije. Prospektivna studija, rađena na Klinici za gastroenterologiju Kliničkog centra u Nišu, uključila je 90 bolesnika sa simptomima GERB-a. Bolesnici su podeljeni u dve grupe prema tome da li imaju endoskopske znake refluksne bolesti (ERB grupa) ili su oni odsutni (NERB grupa). Kod svih bolesnika su tokom proksimalne endoskopije uzimane biopsije iz antruma i korpusa za odredjivanje $H$. pylori infekcije i četiri biopsije iz jednjaka na $2 \mathrm{~cm}$ od $Z$ linije. $U$ želudačnim biopsijama ispitivano je prisustvo $H$. pylori infekcije, kao i histološke promene, bojene hematoksilinom eozinom i modifikovanom metodom Giemsa. Stepen ezofagitisa je određivan po Los Angeles klasifikaciji. Kod bolesnika sa $H$. pylori pozitivnim nalazom sprovedena je eradikaciona terapija u trajanju od 10 dana. Nakon sprovedene eradikacione terapije i lečenja refluksne bolesti 8 nedelja inhibitorima protonske pumpe, ponovljena je biopsija sluzokože jednjaka na već opisani način.

$\mathrm{U}$ antrumu, $H$. pylori je pozitivan kod $22(44,89 \%)$ ispitanika ERB grupe u odnosu na $30(66,66 \%)$ pozitivnih ispitanika NERB grupe. U korpusu, $H$. pylori pozitivan je kod 18 $(40,00 \%)$ ispitanika ERB grupe u odnosu na $24(53,33 \%)$ ispitanika NERB grupe, bez statističke značajnosti. U grupi ERB, nije bilo razlike u prisustvu ili odsustvu $H$. piylori infekcije i stepena težine ezofagitisa. Nakon eradikacije, u grupi bolesnika sa ERB i NERB postoji statistički značajno poboljšanje histološkog nalaza. Nakon terapije, u grupi ispitanika sa ERBom je statistički značajno ređi endoskopski nalaz ezofagitisa $\left(\chi^{2}=22,26 ; p=0,00001\right)$. Nakon terapije, u grupi ispitanika sa NERB-om, tri ispitanika su imala endo-skopski nalaz ezofagitisa.

Kod bolesnika sa GERB treba da se sprovede dugoročna antisekretorna terapija. $H$. pylori treba da se testira i eradicira. H.pylori pozitivan status retko se sreće zajedno sa GERBom, a ukoliko je prisutan, lakog je stepena.

Acta Medica Medianae 2018;57(4):60-66.

Ključne reči: GERB ERB, NERB, H. pylori 